\title{
Polysemes and Synonym Language Stock: Linguistic Evidence from English to Arabic Translation
}

\author{
Dr. Mohammad Awad Al-Dawoody Abdulaal \\ Lecturer of Linguistics, Department of English, \\ Faculty of Arts, Port Said University
}

\begin{abstract}
This research study aims at investigating the reason lying behind EFL learners' inability to construe polysemes to output a coherent text while translating from English into Arabic. The researcher, therefore, hypothesizes that there is a rapport between the learners' inability to translate polysemous words and their poor synonym language stock. To test this hypothesis, two groups experimental and control - were formed; the former consisted of 82 senior EFL learners (51 females and 32 males) in the Department of English, the Faculty of Arts, Port Said University; and the latter was made up of 67 senior learners belonging to the same educational institution. The experimental group was given two pre-tests: translation and synonym, followed by a treatment which in turn followed by two post-tests. The control group, given no treatment, conducted two post-tests. The basic research finding was the positive co-efficient correlation between the ability to construe polysemous words and the synonym language stock. To set an account for this rapport, the researcher postulated that the polysemous words are processed on layers on the semantic level. That is, a lexical item with a sole meaning is processed at layer 1, whereas lexical items with two or more meanings go up to the next layer and then goes to a third providing it still has further semantic contexts.
\end{abstract}

\section{Keywords:}

Polysemes, Synonym Language Stock, Semantic Layers, SoloSemantic Items. 


\section{الكلمات المتعددة المعاني والمخزون اللغوي من المترادفات: دليل لغوي من الترجمة الانجليزية إلي العربية}

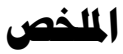

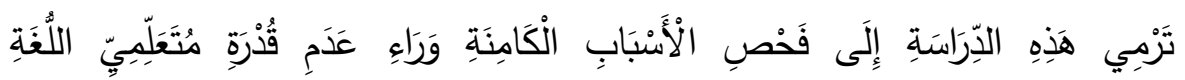

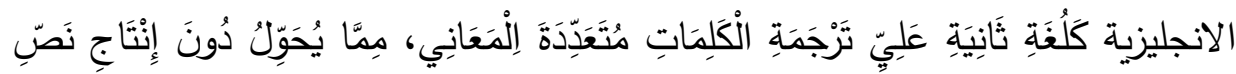

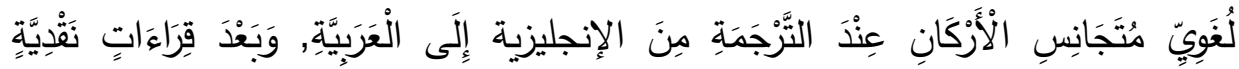

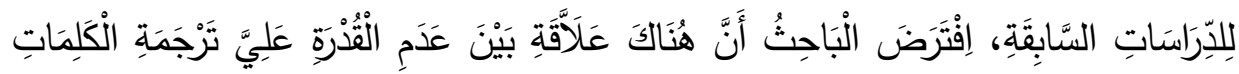

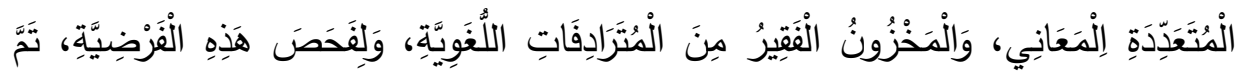

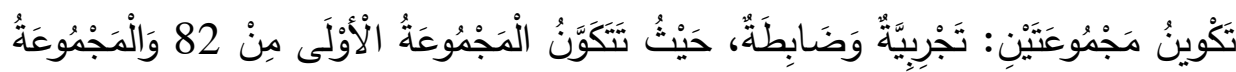

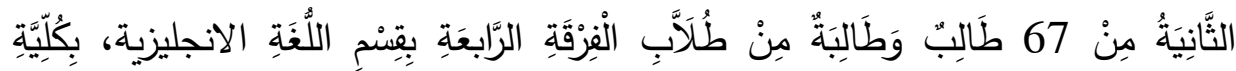

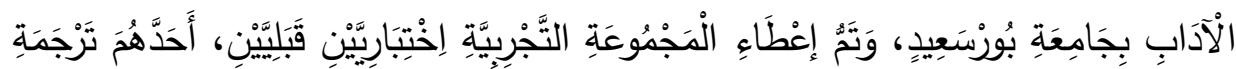

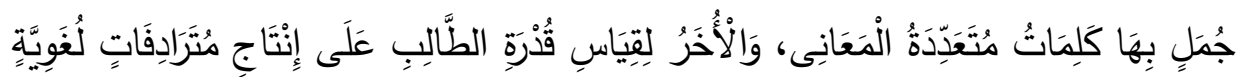

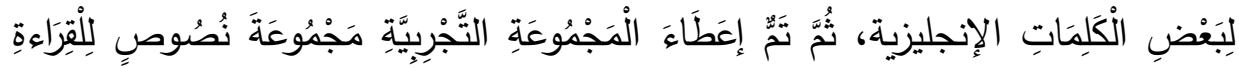

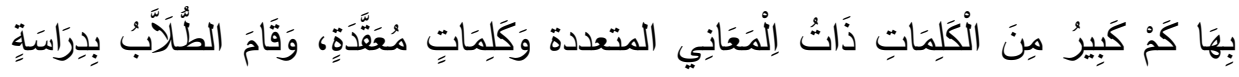

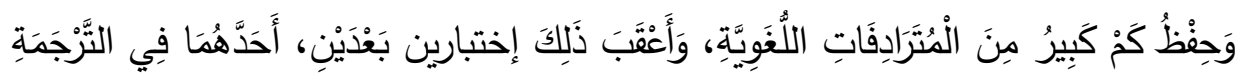

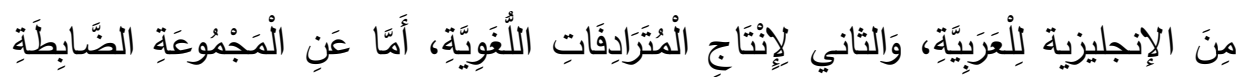

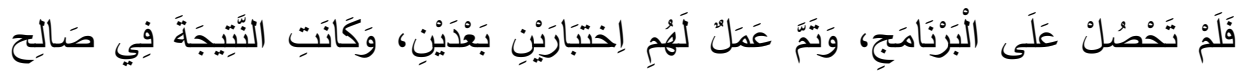

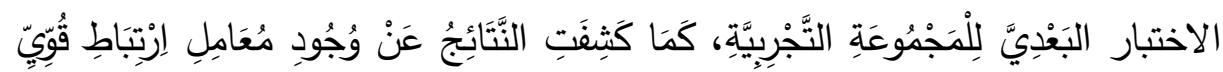

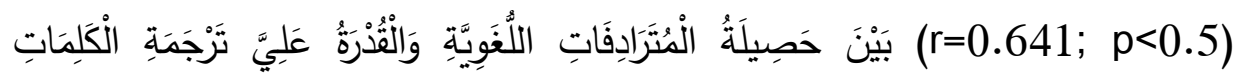

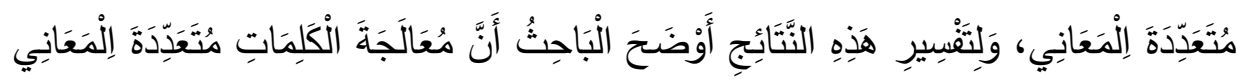

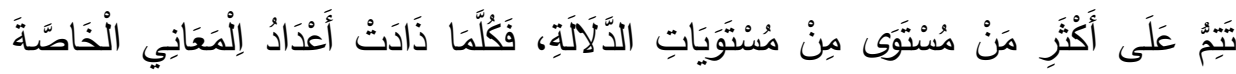

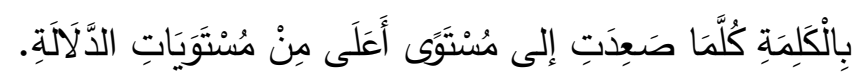

الكانمات الإفتاهية:

الكلمات متعددة المعاني- الكلمات وحيدة المعني- المستوى الدلالي- المخزون 
Polysemes and Synonym Language Stock:

Linguistic Evidence from English to Arabic Translation

Dr. Mohammad Awad Al-Dawoody Abdulaal

مجلة وادي النيل للار اسات و البحوث الإنسانية والاجتماعية و التربوية (مجلة علمية محكمة)

\section{Introduction}

Admittedly, it is not a facile task to find the words which are tantamount to those in the target language to generate a tenacious message when kicking off the translation process. This is, in reality, not the only predicament encountered by EFL learners, but they also come up against some different kinds of problems when translating messages from English into Arabic. These translation problems may be attributed to lexical or grammatical aspects. One of these lexical problems is translating English polysemous words (Enany, 1994; Brenda, 2014; Robinson, 2014).

A polysemy is a word with multiple different meanings, related in location, structure or function. A polyseme is opposed to solosemantic items, sometimes called 'monosemy' which describes a word with a single meaning (Hatim \& Mason, 1990; Ghazala, 2008; Hornby, 2008). The problem arisen on translating polysemous words is basically of a pragmatic nature, and many EFL learners have difficulty in picking up the set meaning. Hence, the contextual environment (i.e. the historical and cultural aspects of the message and the intended audiences) plays a pivotal role in picking up the most appropriate meanings for such words (Newmark, 1981; Palmer, 1981; Baker, 1992; Byrne, 2006; Hornby,2008; Glynn, 2014)).This study, hence, is an endeavor to look for a linguistic aspect closely correlated to the contextual environment and has the capacity to accelerate the process of translating polysemous words from English to Arabic. To achieve this aim, some linguistic literatures are reviewed in the upcoming section with the attempt to get close to the nature of polysemous words and how translators deal with them.

\section{Theoretical Framework}

Most of the linguistic literature dealing with polysemy kicks off with its concept and the distinction between polysemy and other semantic terminologies. Polysemy, sometimes called radiation, 
takes place when a lexical item gets more than a single semantic content (Palmer, 1976; Newmark, 1991; Nida, 1998). Used in a text, polysemy often leads to ambiguity and causes problems for EFL learners. There is a substantial distinction between polysemy and homonymy that should be addressed before investigating the ambiguity effect of polysemy on EFL learners when attempting to construe a text. A polysemous word, on one hand, is a single lexical item with miscellaneous different but functionally or structurally related meanings, for instance, the word 'foot' may refer to the lowest part of the leg or the lowest part of the mountain. The two meanings are different, but they are related in terms of location rather than function or structure. Homonyms, on the other hand, are lexical items with multiple meanings with either the same pronunciation or spelling; for example, the words 'knight' (i.e. a cavalier) and 'night' (i.e. the night time). Unlike homonyms, polysemes are lexical items that have one focal meaning and some peripheral senses; one of these senses always takes over and becomes the key meaning (Baldinger, 1980; Bell, 1987; Bell, 1991; Armstrong, 2005; Tyler, 2012; Ardila, 2017)

Ghazala (1995) pointed out that the translators may be familiar with the common sense of a polyseme and often translate it into Arabic using its sole sense. It indicates that the translators grasp it as a monosemic word, having a sole sense merely; therefore, they may make perilous bloopers. For example, the translators always render the word 'break' as كسر/kasara /; however, it has different renderings in the following contexts: (1) 'You intentionally break the law' and (2) 'The dawn breaks at 5:20'. Armstrong (2005), depending on the results of Ghazala (1995), discussed the synonyms which are polysemes as well, pointing out the role played by word limitation to translate these words properly. His study illustrates how convoluted it is to render polysemes from the source language to the target one as these types of words have various collocations, differing from one language to another, which define their senses. Armstrong (2005) concluded that whether two polysemous words are regarded as near synonyms or not, the translator has to refer to the linguistic context which determines 
Polysemes and Synonym Language Stock:

Linguistic Evidence from English to Arabic Translation

Dr. Mohammad Awad Al-Dawoody Abdulaal

مجلة وادي النيل للار اسات والبحوث الإنسانية والاجتماعية والتربوية (مجلة علمية محكمة)

what he called 'the selectional restrictions' (i.e. which sense imposed by the context to output a coherent message).Armstrong relied vastly on the results reported by Mason (1978) who investigated the effects of polysemous words on sentence comprehension. Mason mainly intended to reveal polysemy impact reading for learners at sixth grade, and then comparing their polysemy comprehension to that of adults. Mason concluded that without context these polysemous words can be dubbed by more than a single sense and that only via context it will get a given meaning.

Some Arab linguists referred to the concept of polysemy as "verbal sharing" (Al-Jürjani, 1954, p.365). As-Suyüti (1971), on the one hand, pointed out that polysemous words not only enrich the language but also make it capable of portraying the physical world around us. However he went against the premise saying that sharing is grounded on the idea that one lexical item has various meanings. Rather, he argued that all sorts of sharing of one expression have a single general semantic content. Ibn Darstwinni (1974), on the other hand, rejected the existence of polysemes in Modern Standard Arabic and asserted that if the polysemes existed, they would take place between two languages and because of what linguists call speech economy. According to Al-Munjid (1999), unlike Ibn Darstwinni (1974), polysemy is one of the linguistic commonalities in all languages. He regarded polysemy as a type of semantic multiplicity.

\section{Problem Statement}

Particularly on translating from English to Arabic, most of translation predicaments are noticed at the word level. EFL learners often come up against difficulties in finding the appropriate meaning for a polyseme to form an Arabic coherent target. Consequently, they often go awry to transfer the message. This study attempts to answer the following question: What is the major reason that lies behind the EFL learners' inability to construe polysemous words from English to Arabic? 
(ISSN : 2536 - 9555)

\section{Research Questions}

Depending on the research problem stated above, this research study endeavors to approach the following questions:

1. Is there a rapport between the learners' inability to translate polysemous words and their poor synonym language stock?

2. Is the mean of the scores of the translation post-test different from that of the scores of the translation pre-test in the experimental group?

3 . Is the mean of the scores of the synonym post-test different from that of the scores of the synonym pre-test in the experimental group?

4. Are there any noticeable differences between the scores of the experimental group and those of the control group on the translation and synonym tests?

\section{Research Hypotheses}

Depending on the research questions raised above, the researcher formulates the following arguments:

1. There is a significant correlation between the participants' scores on the translation pre-test and the synonym pre-test in the experimental group.

2. There are statistically significant differences between the mean of the participants' scores on the translation post-test and the translation pre-test in the experimental group.

3. There are statistically significant differences between the mean of the participants' scores on the synonym post-test and the synonym pre-test.

4. There are statistically significant differences between the means of the participants' scores on the translation and synonym post-tests in the experimental group and the control group.

\section{Significance of the Study}

Monosemic words do not generate problems in meaning, whereas polysemous words do. Consequently, this research study

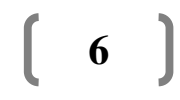


Polysemes and Synonym Language Stock:

Linguistic Evidence from English to Arabic Translation

Dr. Mohammad Awad Al-Dawoody Abdulaal

مجلة وادي النيل للار اسات والبحوث الإنسانية والاجتماعية والتربوية (مجلة علمية محكمة)

attempts to reveal reasons lying behind such a problem via investigating the linguistic aspect closely related to a polyseme, and which in turn can accelerate the translation process. Further, it seeks to set an account for the way the polysemous words are processed at the semantic level on contrary to solo-semantic items.

\section{Methodology}

\subsection{Research tools}

In this study, two research tools are used for data collection:

[1] A written test, designed by the researcher, with many polysemous words in which $4^{\text {th }}$ year EFL participants in the Department of English at the Faculty of Arts, Port Said University were requested to answer by construing from English to Arabic (See 1 below).

[2] A written test, designed by the researcher, was performed by the participants to reveal their synonym language stock (See Appendix B).

In test 1, the participants were requested to translate 30 sentences (See [1] below) which encompass 15 polysemous words (i.e. plant, opaque, scourge, catch on, conceive, pen, shed, convoluted, hit, spoil, alight, buck, avocation, sloppy, and immaculate). Each polysemous word was displayed in two sentences with different contexts as table (1) shows. It was designed to measure the participants' abilities to elicit the appropriate meaning from different contexts.

(1)

1. They intend to spend $\$ 700$ million on an engine plant.

2. Kindly, don't forget to water our plants.

3 . It is a shower with a highly opaque glass door.

4. His style of writing is totally opaque.

5. The scourge of unemployment should be encountered.

6. He used a scourge to punish his servant.

7. The learners can't catch on what the teacher says. 
مجلة وادي النيل للاراسات والبحوث الإنسانية و الاجتماعية والتربوية (مجلة علمية محكمة)

(ISSN : 2536 - 9555)

8. The idea caught on fast.

9. The scientists conceived the notion of the atom in the 1940s.

10. Many women have difficulty in conceiving.

11. Please fill out the form in pen.

12. The farmer erected a sheep pen.

13. She goes on a diet to shed some pounds.

14. They used to keep their ladders in the tool shed.

15. Your style is marked by the use of convoluted sentences.

16. The tube is tightly-coiled and convoluted.

17. He raised the hammer and hit the bell.

18. His song scored the biggest hit in 1930s.

19. The looters in France carried all their spoils away.

20. There are a lot of spoil heaps in the street corners.

21. She alighted from the train at 74th Street.

22. The car was set alight and pushed over a hill.

23. It costs me thirty bucks.

24. South Africans are interested in breeding bucks.

25. She has no full- time avocation.

26. Drawing is one of my avocations.

27. Wendy was dressed in a sloppy blue sweater.

28 . His written reports are considerably sloppy.

29. He is dressed in an immaculate black suit.

30. Your performance has been immaculate.

Table (1) Polysemes in different contexts

\begin{tabular}{|l|l|l|}
\hline Polyseme & $\mathbf{1}^{\text {st }}$ sentence meaning & $\mathbf{2}^{\text {nd }}$ sentence meaning \\
\hline 1. Plant & Factory & Flora or vegetation \\
\hline 2. Opaque & Non-translucent & Fuzzy and vague \\
\hline 3. Scourge & Crisis & Whip \\
\hline 4. Catch on & Understand & Become popular \\
\hline 5. Conceive & Think of & Become pregnant \\
\hline 6. Pen & Biro & Corral \\
\hline 7. Shed & Get rid of & Hideout \\
\hline 8. Convoluted & Sophisticated & Having twists and bends \\
\hline 9. Hit & Pummel & Success \\
\hline 10. Spoil & Booty & Tailings \\
\hline 11. Alight & Get off & Blazing \\
\hline 12. Buck & American dollar & Male deer \\
\hline 13. Avocation & Profession & Hobby \\
\hline & &
\end{tabular}


Polysemes and Synonym Language Stock:

Linguistic Evidence from English to Arabic Translation

Dr. Mohammad Awad Al-Dawoody Abdulaal

\begin{tabular}{|c|c|c|}
\hline \multicolumn{3}{|c|}{ مجلة وادي النيل للار اسات والبحوث الإنسانية والاجتماعية والتربوية (مجلة علمية محكمة) } \\
\hline 14. Sloppy & Filthy & Careless \\
\hline 15. Immaculate & Clean & Perfect \\
\hline
\end{tabular}

In the second test, the participants were given 10 Arabic words ,صادم ,هام, ,يدعم, يسرق , يفهم , كفء , بشع , واضح مجتهد , غامض ,صعب ,سهل) ( (ضخم ,أخرق ,يسرق ,اجنماعي) and requested to set three synonyms for each. This test is designed to explore the learners' synonym stock (See Appendix B).

\subsection{Participants}

The study sample consists of two groups: experimental and control. The experimental group consists of 82senior EFL learners (51 females and 32 males) in the Department of English, the Faculty of Arts, Port Said University in the academic year 2017/2018. Steven K. Thompson's equation is used to calculate the sample size (see 2 below). Seeking the external validity and representativeness, the researcher randomly selected the participants out of 105 - student class. The participants were approximately aged the same and included males and females with different achievement records. Precisely, they were $26 \mathrm{~A}$ and $25 \mathrm{~B}$ female learners in addition to $16 \mathrm{~A}$ and $17 \mathrm{~B}$ male learners. As regards the internal validity of the research instruments used in this study, both the translation tests were submitted to some experts who are $\mathrm{PhD}$ holders and instructors of literature and linguistics in the Departments of English at the Faculties of Arts in Port Said, Suez Canal, Suez, and Sattam Bin Abdul-Aziz Universities. After consulting these juries and taking their comments and suggestions, some modifications were conducted on the two tests to make them suitable and valid to be administered.

$$
n=\frac{\mathrm{N} \mathrm{p}(1-\mathrm{p})}{(N-1)(\mathrm{d} 2 / z 2)+p(1-p)}
$$

Where $\mathrm{n}=$ sample size (82); $\mathrm{N}=$ Population size (105); $\mathrm{z}=$ confidence level at $0.95 \%(1.96)$; $d=$ error proportion $(0.05) ; \mathrm{p}=$ probability $(50 \%)$ 
مجلة وادي النيل للاراسات والبحوث الإنسانية والاجتماعية والتربوية (مجلة علمية محكمة)

(ISSN : 2536 - 9555)

\section{Research Procedures}

1. The participants in the experimental group were given the translation and synonym pre-tests and were asked to answer the two tests in 90 minutes. To check the reliability of the two pretests, the participants were retested after a span of three days and the co-efficient correlation was calculated $(r=0.6841$ and $p<0.5)$. To avoid the participant error, the pre-tests were conducted on an open - schedule day chosen by the participants. To avoid the participant bias, the researcher informed the participants not to write their names on the two tests.

2. The participants underwent a comprehensive synonym-based course. The researcher selected some advanced reading passages full of new vocabulary (See in Appendix [A] examples of the synonyms extracted from the reading passages taught to the participants) these reading passages were intended to bolster the participants' synonym stock. The treatment has lasted for three successive weeks (two-classes per week).

3. The participants underwent 90-minutetranslation and synonym post-tests to check the effect of the treatment given. To check the reliability of the post test, the researcher retested the participants after a span of 6 days and the co-efficient correlation was calculated $(r=0.752$ and $p<0.5)$.

4. The control group, a sample of 67 senior learners belonging to the same educational institution and with the same age as the experimental group, was selected out of 80 learners and asked to carry out translation and synonym post-tests with no prior intervention.

5. The normality test was conducted to check the normal distribution in the two tasks. A Shapiro-Wilk's test ( $>$ >.05; PreTest $(\mathrm{T})=21 \%$ and Pre-Test $(\mathrm{S})=32.1 .9 \%)$ and a visual inspection of their histograms, normal Q-Q plots and box plots showed that the scores were normally distributed for the two tasks with a skewness of approximately 0.1 and 0.2 for Pre-Test (T) and PreTest (S) respectively; and a kurtosis of 2.945 for the translation test and 2.952 for the synonym test (See Table $2 \&$ Appendix C). 
Polysemes and Synonym Language Stock:

Linguistic Evidence from English to Arabic Translation

Dr. Mohammad Awad Al-Dawoody Abdulaal

مجلة وادي النيل للاراسات والبحوث الإنسانية والاجتماعية والتربوية (مجلة علمية محكمة)

Table (2) : Normality Distribution of Pre-tests

\begin{tabular}{|c|c|c|c|c|c|c|}
\hline \multirow{2}{*}{ Pre-tests } & \multicolumn{2}{|c|}{ Kolmogorov-Smirnov ${ }^{\mathrm{a}}$} & \multicolumn{3}{c|}{ Shapiro-Wilk } \\
\cline { 2 - 7 } & Statistic & Df & Sig. & Statistic & Df & Sig. \\
\hline Pre-Test [T] & .160 & 82 & .085 & .948 & 82 & .210 \\
\hline Pre-Test [S] & .173 & 82 & .145 & .840 & 82 & .321 \\
\hline
\end{tabular}

6. After the treatment had been given, the normality test was conducted again to check the normal distribution in the two posttasks (i.e. translation and synonym). A Shapiro-Wilk's test ( $\mathrm{p}>.05$; Post-Test $(\mathrm{T})=12.5 \%$ and Post-Test $(\mathrm{S})=41.1 \%$ ) and a visual inspection of their histograms, normal Q-Q plots and box plots showed that the scores were normally distributed for the two tasks with a skewness of approximately 0.22 and 0.014 for Post-Test(T) and Post Test (S) respectively; and a kurtosis of 2.895 for the translation test and 2.981 for the synonym test (See Table 3\& Appendix D).

Table (3) Normality Distribution of Post-Tests

\begin{tabular}{|c|c|c|c|c|c|c|}
\hline \multirow{2}{*}{ Post-tests } & \multicolumn{2}{|c|}{ Kolmogorov-Smirnov } & \multicolumn{4}{c|}{ Shapiro-Wilk } \\
\cline { 2 - 7 } & Statistic & Df & Sig. & Statistic & Df & Sig. \\
\hline Post-Test [T] & .143 & 81 & .074 & .889 & 81 & .125 \\
\hline Post-Test [S] & .141 & 81 & .231 & .947 & 81 & .411 \\
\hline
\end{tabular}

\section{Results}

Eighty - two learners were surveyed about their ability to translate polysemous words $(\mathrm{M}=15.71, \mathrm{SD}=2.338)$ and their ability to generate synonyms for some Arabic words $(M=16.81$, $\mathrm{SD}=4.106)$. A Pearson's $\mathrm{r}$ analysis revealed a strong positive correlation, $r=0.641(p<0.5)$. It means that the learners who have the ability to translate polysemous words can generate many English synonyms for Arabic words. The Pearson's $r$ analysis also 
مجلة وادي النيل للاراسات والبحوث الإنسانية والاجتماعية والتربوية (مجلة علمية محكمة)

(ISSN : 2536 - 9555)

revealed that those participants with low scores in translation test have also obtained low scores in the synonym test (See Table 4).

Table (4) : Correlations

\begin{tabular}{|c|l|c|c|}
\hline \multirow{4}{*}{ Pre-Test [T] } & Pearson Correlation & 1 & .641 \\
\cline { 2 - 4 } & Sig. (2-tailed) & & .000 \\
\cline { 2 - 4 } & $\mathrm{N}$ & 82 & 82 \\
\hline \multirow{3}{*}{ Pre-test [S] } & Pearson Correlation & .641 & 1 \\
\cline { 2 - 4 } & Sig. (2-tailed) & .000 & \\
\cline { 2 - 4 } & $\mathrm{N}$ & 82 & 82 \\
\hline
\end{tabular}

To test the effectiveness of the treatment given, a paired sample t-test was performed between pre-test [T] $(M=14.68 ; S D=2.303)$ and post-test $[\mathrm{T}](M=25.62 ; S D=2.809)$. Prior to conducting the analysis, the assumption of normally distributed scores was examined, and the assumption was considered satisfied (See tables $1 \& 2)$ as the skewness and kurtosis are less than the maximum allowable values for a t-test (i.e. skewness $=0$; kurtosis $=3$ ). It is also noted that the correlation between Pre-Test [T] and Post -Test [T] was estimated $(r=.105, p<.001)$ suggesting that the t-test is appropriate in this case (see table 6). The null hypothesis $\left(\mathrm{H}_{0}\right.$ : $\mu_{1}=\mu_{2}$ ) was rejected as table (5) shows. Thus, the alternative hypothesis $\left(\mathrm{H}_{1}: \mu_{1} \neq \mu_{2}\right)$ was accepted; it showed that the treatment given was highly effective. Since $\mu_{2}>\mu_{1}$, (as the difference between the two means is 10.94) the treatment given bolstered the subject's capacities to translate polysemous words (see table 5).

To test the effectiveness of the synonyms given to the subjects, another paired sample t-test was performed between pre-test [S] $(M=15.15 ; S D=4.104)$ and post-test $[\mathrm{S}](M=24.90 ; S D=2.307)$. Before conducting the analysis, the normality test was performed to make sure that the data were normally distributed, and the assumption was regarded satisfied (See tables 1 \&2) as the skewness and kurtosis are less than the maximum allowable values for a t-test (i.e. skewness $=0$; kurtosis $=3$ ). It is also noted that the correlation between Pre-Test [S] and Post-Test [S] was evaluated $(\mathrm{r}=.085, \mathrm{p}<.001)$ suggesting that the $\mathrm{t}$-test is appropriate in this 
Polysemes and Synonym Language Stock:

Linguistic Evidence from English to Arabic Translation

Dr. Mohammad Awad Al-Dawoody Abdulaal

مجلة وادي النيل للار اسات و البحوث الإنسانية و الاجتماعية والتربوية (مجلة علمية محكمة)

case (see table 6 ). The null hypothesis $\left(\mathrm{H}_{0}: \mu_{1}=\mu_{2}\right)$ was turned down as table (5) illustrates. Thence, the alternative hypothesis $\left(\mathrm{H}_{1}: \mu_{1} \neq \mu_{2}\right)$ was assented; it indicated that the synonym treatment given was highly effective. Since $\mu_{2}>\mu_{1}$, (as the difference between the two means is 9.756) the treatment given underpinned the participants' capacities to generate synonyms.

Table (5) Paired Samples Statistics

\begin{tabular}{|c|l|c|c|c|c|}
\hline \multicolumn{2}{|c|}{ Pairs 1\&2 } & Mean & N & Std. Deviation & Std. Error Mean \\
\hline \multirow{2}{*}{ Pair 1 } & Pre-Test [T] & 14.68 & 82 & 2.303 & .254 \\
\cline { 2 - 6 } & Post-Test [T] & 25.62 & 82 & 2.809 & .310 \\
\hline \multirow{2}{*}{ Pair 2 } & Pre-test $[$ S] & 15.15 & 82 & 4.104 & .453 \\
\cline { 2 - 6 } & Post-Test $[$ S] & 24.90 & 82 & 2.307 & .255 \\
\hline
\end{tabular}

Table (6) Paired Samples Correlations

\begin{tabular}{|l|l|c|c|c|}
\hline \multicolumn{2}{|c|}{ Pairs 1\&2 } & N & Correlation & Sig. \\
\hline Pair 1 & Pre-Test [T] \& Post-Test [T] & 82 & $-.105-$ & .350 \\
\hline Pair 2 & Pre-test [S] \& Post-Test [S] & $\mathbf{8 2}$ & .085 & .448 \\
\hline
\end{tabular}

The T-test for two independent groups was conducted to validate the hypothesis that there is a statistically significant difference between the participants' scores on the translation test in the experimental group and the scores of the control group on the same test. Table (8) presents the results of Levene's test which confirmed homogeneity between the two groups since $\mathrm{p}>0.05$ (\%9.6). In other words, the null hypothesis (HO) was accepted and the alternative (H1) one was turned down. The second part of the test shows that $\mathrm{p}<0.05$, thus the null hypothesis indicating that $\mu 1=\mu 2$ was rejected and the alternative one stating that $\mu 1 \neq \mu 2$ was assented. Table (7) shows how effective the treatment was as the mean of the scores of experimental group has doubled the mean of those of the control group. 
مجلة وادي النيل للاراسات والبحوث الإنسانية و الاجتماعية والتربوية (مجلة علمية محكمة)

(ISSN : 2536 - 9555)

(7) Group Statistics

\begin{tabular}{|r|r|c|c|c|c|}
\hline & Codes & N & Mean & Std. Deviation & Std. Error Mean \\
\cline { 2 - 6 } Post-Test [T] & Exp.Post T & 82 & 25.65 & 2.804 & .308 \\
\cline { 2 - 6 } & Control T & 67 & 12.96 & 2.107 & .257 \\
\hline
\end{tabular}

(8) Independent Samples Test

\begin{tabular}{|c|c|c|c|c|c|c|c|c|c|}
\hline \multirow{3}{*}{ Post-Test [T] } & \multicolumn{2}{|c|}{$\begin{array}{c}\text { Levene's Test } \\
\text { for Equality of } \\
\text { Variances }\end{array}$} & \multicolumn{7}{|c|}{ t-test for Equality of Means } \\
\hline & \multirow[t]{2}{*}{$\mathbf{F}$} & \multirow[t]{2}{*}{ Sig. } & \multirow[t]{2}{*}{$\mathbf{T}$} & \multirow[t]{2}{*}{ Df } & \multirow[t]{2}{*}{$\begin{array}{l}\text { Sig. (2- } \\
\text { tailed) }\end{array}$} & \multirow[t]{2}{*}{$\begin{array}{c}\text { Mean } \\
\text { Difference }\end{array}$} & \multirow{2}{*}{\begin{tabular}{|c} 
Std. \\
Error \\
Difference
\end{tabular}} & \multicolumn{2}{|c|}{\begin{tabular}{|c}
$\mathbf{9 5 \%}$ Confidence \\
Interval of the \\
Difference
\end{tabular}} \\
\hline & & & & & & & & Lower & Upper \\
\hline $\begin{array}{l}\text { Equal variances } \\
\text { assumed }\end{array}$ & 2.807 & .096 & 30.709 & 147 & .000 & 12.695 & .413 & 11.878 & 13.512 \\
\hline $\begin{array}{l}\text { Equal variances } \\
\text { not assumed }\end{array}$ & & & 31.642 & 147.289 & .000 & 12.695 & .401 & 11.902 & 13.488 \\
\hline
\end{tabular}

To validate the hypothesis that there is a statistically significant difference between the participants' scores on the synonym test in the experimental group and the scores of the control group on the same test, the T-test for two independent groups was conducted. Table (10) presents the results of Levene's test which confirmed homogeneity between the two groups since $\mathrm{p}>0.05$ (\%7.8). In other words, the null hypothesis $\left(\mathrm{H}_{\mathrm{O}}\right)$, stating the existence of homogeneity, was accepted and the alternative $\left(\mathrm{H}_{1}\right)$, stating the opposite, one was rejected. The second part of the test, the equality of means, shows that $\mathrm{p}<0.05$, thus the null hypothesis, stating that $\mu_{1}=\mu_{2}$, was rejected and the alternative one stating that $\mu_{1} \neq \mu_{2}$ was accepted. Table (9) shows how effective the treatment was as the mean of the scores of experimental group (i.e. 24.90) surpassed the mean of the scores of the control group.

Table (9) Group Statistics

\begin{tabular}{|c|c|c|c|c|c|}
\hline \multirow{3}{*}{$\begin{array}{c}\text { Post-Test } \\
{[S]}\end{array}$} & Codes2 & N & Mean & Std. Deviation & Std. Error Mean \\
\cline { 2 - 6 } & Exp.Post-Test $[$ S & 82 & 24.90 & 2.307 & .255 \\
\cline { 2 - 6 } & Control $[$ S $]$ & 67 & 13.58 & 3.513 & .429 \\
\hline
\end{tabular}


Polysemes and Synonym Language Stock:

Linguistic Evidence from English to Arabic Translation

Dr. Mohammad Awad Al-Dawoody Abdulaal

مجلة وادي النيل للار اسات والبحوث الإنسانية والاجتماعية والتربوية (مجلة علمية محكمة)

Table (10) Independent Samples Test

\begin{tabular}{|c|c|c|c|c|c|c|c|c|c|}
\hline \multirow{3}{*}{ Post-Test [S] } & \multicolumn{2}{|c|}{$\begin{array}{l}\text { Levene's Test } \\
\text { for Equality } \\
\text { of Variances }\end{array}$} & \multicolumn{7}{|c|}{ t-test for Equality of Means } \\
\hline & \multirow[t]{2}{*}{$\mathbf{F}$} & \multirow[t]{2}{*}{ Sig. } & \multirow[t]{2}{*}{$\mathbf{T}$} & \multirow[t]{2}{*}{ Df } & \multirow[t]{2}{*}{$\begin{array}{c}\text { Sig. } \\
(2-\text { tailed })\end{array}$} & \multirow[t]{2}{*}{$\begin{array}{l}\text { Mean } \\
\text { Difference }\end{array}$} & \multirow[t]{2}{*}{$\begin{array}{l}\text { Std. Error } \\
\text { Difference }\end{array}$} & \multicolumn{2}{|c|}{$\begin{array}{c}95 \% \text { Confidence } \\
\text { Interval of the } \\
\text { Difference } \\
\end{array}$} \\
\hline & & & & & & & & Lower & Upper \\
\hline $\begin{array}{l}\text { Equal variances } \\
\text { assumed }\end{array}$ & 3.154 & .078 & 23.615 & 147 & .000 & 11.320 & .479 & 10.373 & 12.268 \\
\hline $\begin{array}{l}\text { Equal variances } \\
\text { not assumed }\end{array}$ & & & 22.683 & 109.6 & .000 & 11.320 & .499 & 10.331 & 12.309 \\
\hline
\end{tabular}

\section{Discussion}

The results presented in the previous section and precisely the scores of the participants in the translation and the synonym pretests clearly showed that $4^{\text {th }}$-year EFL learners at the Faculty of Arts, Port Said University were not familiar with polysemous words. Over and above, the results displayed the robust rapport between the learners' inability to translate polysemous words and their poor synonym language stock. The correlation between the participant's ability to render a polysemous word and his or her synonym language stock turned out to be substantially positive. That is to say, the participant's ability to render polysemous words recedes or rises with the paucity or the abundance of the participant's synonym stock; this research finding validated the first hypothesis and underpinned the study's basic argument which postulates that one's ability to render words with multiple semantic contexts is fostered by a synonym faculty. As the given treatment showed, the synonym faculty is multilayered and formed via 
extensive reading texts of an advanced level. This study, depending on the way by which the treatment was given, showed that the words with sole semantic context remained in layer 1(e.g. mop), but polysemous words jump up to the second layer to be attached with its lexemes as the graph below shows (e.g. scourge); but if the word has a third different meaning, the lexeme will go up to layer 3 (e.g. plant).This argument goes in accordance with Alnamer (2017), Mason, Kniseley, and Kendall (1979) who postulated that words with multiple semantic contexts cannot be processed at a single layer at the semantic level.
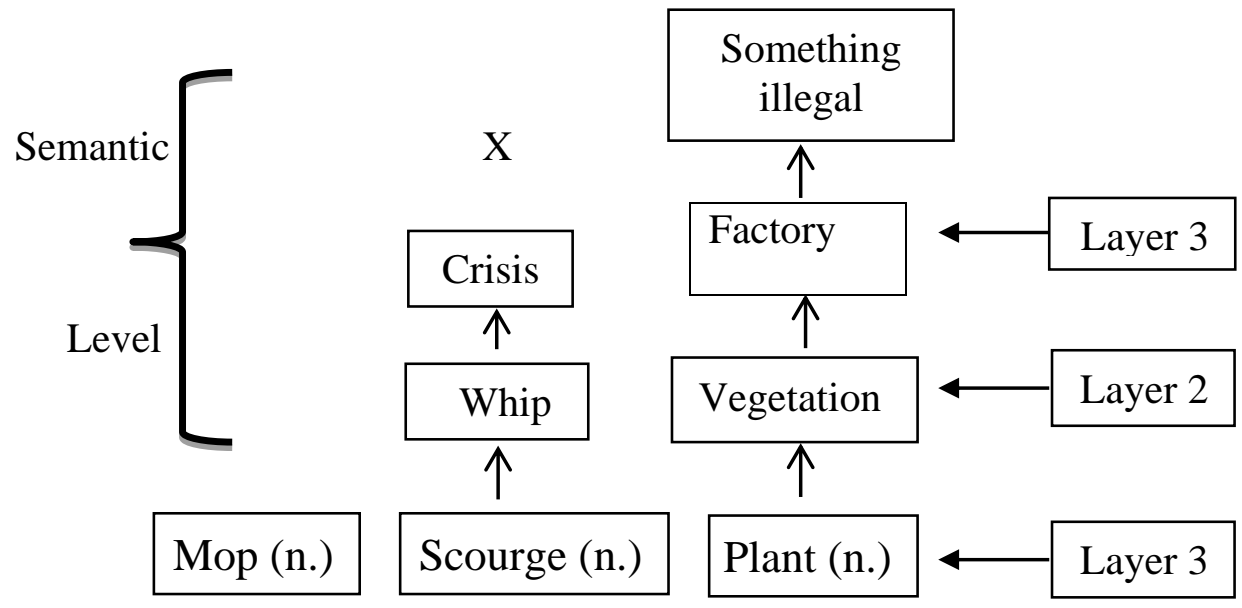

The second research question addresses the relationship between the mean of the scores of the translation post-test and that of the scores of the translation pre-test. The results showed that there were statistically significant differences between the mean of the participants' scores on the translation post-test and the translation pre-test. The mean of the scores of the translation posttest was higher than that of the pre-test; the matter that reflected the efficiency of the treatment given. It was attributed to the comprehensive nature of the treatment given. The vocabulary, the participants dealt with, has been not only convoluted but also sometimes with multiple different meanings. Thus, the high mean of the scores of the post-test was attributed to the amelioration of the kind of the vocabulary given to the participants, who have 
Polysemes and Synonym Language Stock:

Linguistic Evidence from English to Arabic Translation

Dr. Mohammad Awad Al-Dawoody Abdulaal

مجلة وادي النيل للار اسات والبحوث الإنسانية والاجتماعية والتربوية (مجلة علمية محكمة)

rarely been exposed to vocabulary with multiple semantic contexts. This research result goes in accordance with Yurchenko, Lopukhina, and Dragoy (2018) who concluded that the type of Russian vocabulary given to the subjects affected their ability to construe polysemous words.

The third hypothesis was validated as the results showed that there were statistically significant differences between the mean of the participants' scores on the synonym post-test and the synonym pre-test. It was reflected in the scores of the participants' translation post-test. When the participants had brushed up their synonym language stock, the translation faculty in turn was ameliorated. It manifested the close rapport between the close rapport between the participants' ability to translate polysemous words and their rich synonym language stock. Thence, the third and fourth hypotheses bolstered the mutual influence between the synonym stock and the ability to construe polysemous words. The third hypothesis was on the same line with Partridge (2015) who showed the effect of synonym acquisition on dealing with polysemous words.

The fourth hypothesis was validated as the results showed the noticeable differences between the scores of the experimental group and those of the control group on the translation and synonym tests in favor of the experimental group. The control group failed to construe most of the polysemous words and at the same time failed to give more than one synonym for the items given in the synonym test. It was attributed to the fact the translation faculty was disrupted because of the poor synonym supply provided by the synonym stock faculty.

\section{Conclusion}

The $4^{\text {th }}$-year EFL learners at the Faculty of Arts, Port Said University, were proved not to be familiar with polysemous words, lexical items with multiple meanings. This problem was manifested when the participants were asked to render some English polysemous words into Arabic and to give some synonyms 
to some lexical items. This problem appeared not only at the word level but also at the sentence level. To sort out this problem, depending on the positive co-efficient correlation between the ability to construe polysemous words and the synonym language stock, the treatment given focused on enhancing the participants' synonym stock. To set an account for this rapport, the researcher postulated that the polysemous words are processed on layers on the semantic level. That is, a lexical item with a sole meaning is processed at layer 1, whereas lexical items with two or more meanings go up to the next layer and then goes to a third if it still has further semantic contexts.

\section{Acknowledgements}

I'd like to express my sincere appreciation to everyone who boosted me throughout the course of writing this paper: Dr. Mohammad Tohammy, my mentor, Dr. Naglaa Abuslema, a psychologist; Mr. Emad Ali, the principal of Nile School for hosting the participants for two sessions; Dr. Shaker Rizk, a professor of linguistics; Dr. Waleed Rabee, a statistician; Mr. Mohammad Farag, who lent me a hand in data insertion; Dr. Eyaad Abass, an editor; and dear subjects for their patience, understanding, and support.

\section{References}

Alnamer, S. A. (2017). On the Awareness of English Polysemous Words by Arabic-Speaking EFL Learners.Advances in Language and Literary Studies, 8(2), 112. doi:10.7575/aiac.alls.v.8n.2p.112

Ardila, A. (2017). Language disorders, interpreting, and translation. The Routledge Handbook of Translation Studies and Linguistics, 267-280. doi:10.4324/9781315692845-18

Armstrong, N. (2005). Translation, Linguistics, Culture: A French English Handbook. Clevedon: Multilingual Matters LTD.

Baldinger, K. (1980).Semantic Theory. Oxford: Basil Blackwell.

Baker, M. (1992). In Other Words: a Course Book on Translation. London: Routledge. 
Polysemes and Synonym Language Stock:

Linguistic Evidence from English to Arabic Translation

Dr. Mohammad Awad Al-Dawoody Abdulaal

مجلة وادي النيل للاراسات والبحوث الإنسانية والاجتماعية والتربوية (مجلة علمية محكمة)

Brenda, M. (2014). Cognitive perspective on the polysemy of the English spatial preposition over. Newcastle upon Tyne: Cambridge Scholars Press.

Byrne, J. (2006). Technical Translation: Usability Strategies for Translating Technical Documentation. Dordrecht: Springer

Bell, R.T. (1991). Translation and Translating: Theory and Practice. London: Longman Group Ltd.

Bell. J. (1987). Doing Your Research Project. Oxford: Oxford University Press

Ghazala, H. (1995). Translation as Problems and Solutions. Valeta (Malta): Elga Publication.

(2008). Translation As Problems and Solutions. Beirut: Dar El-IimLilmalayin.

Glynn, D. (2014). Polysemy and synonymy. Human Cognitive Processing Corpus Methods for Semantics, 7-38. doi:10.1075/hcp.43.01gly

Hatim, B. \& Mason, I. (1990).Discourse and the Translator. London And New York: Longman.

Hornby, A. (2008). Oxford Advanced Learner's Dictionary. Oxford: Oxford University Press.

Mason, J. (1978). Effects onnf Polysemous Words on Reading Comprehension. Illinois: University of Illinois.

Mason, J. M., Kniseley, E., \& Kendall, J. (1979).Effects of Polysemous Words on Sentence Comprehension. Reading Research Quarterly,15(1), 49. doi:10.2307/747431

Newmark, P. (1981). A Text Book of Translation. New York, London: Prentice Hall. Press.

Nida, E. (1964). Toward a Science of Translating with Special Reference to Principles and Procedures Involved in Bible Translation. Leiden: E.J. Brill. 
مجلة وادي النيل للاراسات والبحوث الإنسانية والاجتماعية والتربوية (مجلة علمية محكمة)

(ISSN : 2536 - 9555)

Palmer, F. (1981).Semantics. Cambridge: Cambridge University Press.

Partridge, E. (2015). Words, Words Words! doi:10.4324/9781315690216

Robinson, J. A. (2014). Quantifying polysemy in Cognitive Sociolinguistics. Human Cognitive Processing Corpus Methods for Semantics, 87-115. doi:10.1075/hcp.43.04rob

Thompson, S. K. (2012). Sampling. Hoboken: John Wiley \& Sons.

Tyler, A. (2012). Spatial Language, Polysemy, and Cross-Linguistic Semantic Mismatches: Cognitive Linguistics Insights into Challenges for Second Language Learners. Spatial Cognition \& Computation, 12(4), 305-335. doi:10.1080/13875868. 2012. 698670

Yurchenko, A., Lopukhina, A., \&Dragoy, O. (2018). Meaning Relatedness in Polysemous and Homonymous Words: An Erp Study in Russian. SSRN Electronic Journal. doi: 10.2139/ ssrn. 3291173

$$
\text { الجرجاني، عبد القاهر (1954). أسرار البلاغة. دار المعارف للنشر. }
$$

السيوطي، عبد الرحمن (1971) ـ المزدهر في علوم اللغة (الطبعة الثالثة). القاهرة:

$$
\text { دار إحياء الكتب العربية. }
$$

المنجد، محمد (1999). الإشتراك اللفظي في القرآن الكريم بين النظرية والتطبيق.

$$
\text { (الطبعة الأولى) دمشق : دار الفكر الإستران }
$$

دار سنويه، عبد الله (1974). تصحيح الفصيح وشرحه القاهرة، تحقيق محمد

$$
\text { بدوي المختون. مطابع الأهرام. }
$$

عناني، محمد (1994). فن الترجمة، الشركة المصرية العالمية للنشر -

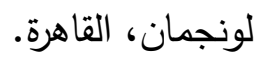

عناني، محمد (1997). الترجمة الأدبية بين النظرية و التطبيق. مكتبة لبنان/الشركة المصرية العالمية للنشر - لونجمان، القاهرة. 
Polysemes and Synonym Language Stock:

Linguistic Evidence from English to Arabic Translation

Dr. Mohammad Awad Al-Dawoody Abdulaal

\begin{tabular}{|c|c|c|}
\hline \multicolumn{3}{|c|}{ مجلة وادي النيل للاراسات و البحوث الإنسانية والاجتماعية والتربوية (مجلة علمية محكمة) } \\
\hline & \multicolumn{2}{|c|}{ Appendix [A] Sheet 1} \\
\hline Vocabulary & Synonym & Translation \\
\hline 1. Ill-bred (adj.) & Uncouth & \\
\hline \multicolumn{3}{|c|}{ e.g. He is a loud-mouthed uncouth child. } \\
\hline 2. Affable & Friendly & \\
\hline \multicolumn{3}{|c|}{ e.g. The bride is very affable. } \\
\hline 3. Attachment & Appendage & \\
\hline \multicolumn{3}{|c|}{ e.g. This center is an appendage to the embassy. } \\
\hline 4. Voracious & Hungry /Eager for stl & \\
\hline \multicolumn{3}{|c|}{ e.g. He's a voracious reader of historical novels. } \\
\hline 5. Sagacity & Wisdom & \\
\hline \multicolumn{3}{|c|}{ e.g. My dad is marked by sagacity. } \\
\hline 6. Salacious & Indecent & \\
\hline \multicolumn{3}{|c|}{ e.g. It is a salacious book. } \\
\hline 7. Paradigm & Model & \\
\hline \multicolumn{3}{|c|}{ e.g. I hate the economic American paradigm. } \\
\hline 8. Ménage & Household & \\
\hline \multicolumn{3}{|c|}{ e.g. He works hard to protect his ménage. } \\
\hline 9. Malaise & Sickness / annoyance & \\
\hline \multicolumn{3}{|c|}{ e.g. Because of some malaise, he will stay home. } \\
\hline 10. Defamation & Slander $=$ libel & \\
\hline \multicolumn{3}{|c|}{ e.g. Holt sued the newspaper for libel. } \\
\hline 11.Urbane & Polite / polished & \\
\hline \multicolumn{3}{|c|}{ e.g. Herschel was an urbane, kindly, and generous man. } \\
\hline 12.Tyranny & Cruelty & \\
\hline \multicolumn{3}{|c|}{ e.g. It was a war against tyranny. } \\
\hline 13.Smear & Mark & \\
\hline \multicolumn{3}{|c|}{ e.g. He smeared his t-shirt with orange juice. } \\
\hline 14.Bizarre & Strange & \\
\hline \multicolumn{3}{|c|}{ e.g. It was a bizarre movie. } \\
\hline 15.Harass & Annoy & \\
\hline \multicolumn{3}{|c|}{ e.g. Stop harassing me. } \\
\hline 16.Innate & Inborn & \\
\hline \multicolumn{3}{|c|}{ e.g. He has innate courage. } \\
\hline 17. Ersatz & Imitation & \\
\hline
\end{tabular}


مجلة وادي النيل للار اسات والبحوث الإنسانبة والاجتماعية والتربوية (مجلة علمية محكمة)

(ISSN : 2536 - 9555)

\section{Appendix [A] Sheet 2}

\begin{tabular}{|c|c|c|}
\hline Vocabulary & Synonym & Translation \\
\hline 1. Go-between & Mediator & \\
\hline \multicolumn{3}{|c|}{ e.g. I do not need a go-between to talk to my dad. } \\
\hline 2. Pound on the door & \begin{tabular}{l|l}
$\cdot$ & Knock at the door \\
\end{tabular} & \\
\hline \multicolumn{3}{|c|}{ e.g. Stop pounding on the door } \\
\hline 3.Scuttle & Run quickly & \\
\hline \multicolumn{3}{|c|}{ e.g. I saw the rat scuttling in the field. } \\
\hline 4. Reluctant & Unwilling & \\
\hline \multicolumn{3}{|c|}{ e.g. I asked me for help, but I was reluctant. } \\
\hline 5. $\operatorname{Cozy}=\cos y$ & Warm & \\
\hline \multicolumn{3}{|c|}{ e.g. I feel cozy, so I will not go out now. } \\
\hline 6. Glistening & Sparkling & \\
\hline \multicolumn{3}{|c|}{ e.g. Your dress was glistening. } \\
\hline 7. Nasty & Very bad & \\
\hline \multicolumn{3}{|c|}{ e.g. There's a nasty smell in here. } \\
\hline 9. Disruption & Nuisance & \\
\hline \multicolumn{3}{|c|}{ I hate to be a nuisance, but I came for a matter of urgency. } \\
\hline 10. Refined & Polite & \\
\hline \multicolumn{3}{|c|}{ e.g. He is a refined person. } \\
\hline 11. Unseemly & Uncomely & \\
\hline \multicolumn{3}{|c|}{ e.g. Your proposal is uncomely. } \\
\hline 12. Consent & Approval & \\
\hline \multicolumn{3}{|c|}{ e.g. Without your consent, we cannot travel abroad. } \\
\hline 13. Abruptly & Suddenly & \\
\hline \multicolumn{3}{|c|}{ e.g. The accident took place abruptly. } \\
\hline 14. Startle & Surprise & \\
\hline \multicolumn{3}{|c|}{ e.g. Your answer startles me. } \\
\hline 15. Preposterous & Unreasonable/ absurd & \\
\hline \multicolumn{3}{|c|}{ e.g. Your request was preposterous. } \\
\hline 16. In the snap of my $f$ & Quickly & \\
\hline \multicolumn{3}{|c|}{ e.g. I can solve the problem in the snap of my fingers. } \\
\hline 17. Reminisce & Remember past events & \\
\hline \multicolumn{3}{|c|}{ e.g. My grandfather used to reminisce about his years in the navy. } \\
\hline 18. Anecdote & Tale / Story & \\
\hline
\end{tabular}


Polysemes and Synonym Language Stock:

Linguistic Evidence from English to Arabic Translation

Dr. Mohammad Awad Al-Dawoody Abdulaal

\begin{tabular}{|c|c|c|}
\hline \multicolumn{3}{|c|}{ مجلة وادي النيل للار اسات و البحوث الإنسانية والاجتماعية والتربوية (مجلة علمية محكمة) } \\
\hline & Appendix [A] Sheet 3 & Sheet 3 \\
\hline Vocabulary & Synonym & Translation \\
\hline 1. Verbatim & Word for word & \\
\hline \multicolumn{3}{|c|}{ e.g. He writes the president's speech verbatim. } \\
\hline 2. Stubborn & Obstinate & \\
\hline \multicolumn{3}{|c|}{ e.g. I hate stubborn students. } \\
\hline 3. Symbiosis & Close association & \\
\hline \multicolumn{3}{|c|}{ e.g. There is a strong symbiosis between France and USA. } \\
\hline 4. Turbulence & Commotion & \\
\hline \multicolumn{3}{|c|}{ e.g. The era was characterized by political and cultural turbulence. } \\
\hline 5. Precarious & Uncertain ; Unstable & \\
\hline \multicolumn{3}{|c|}{ e.g. She leads a precarious livelihood. / e.g. It is a precarious conclusion } \\
\hline 6. Mercenary & Serving for pay & \\
\hline \multicolumn{3}{|c|}{ e.g. He hired mercenary troops to invade France. } \\
\hline 7. Obscene & Indecent & \\
\hline \multicolumn{3}{|c|}{ e.g. Obscene scenes should be omitted from movies. } \\
\hline 8. Exacerbate & Aggravate & \\
\hline \multicolumn{3}{|c|}{ e.g. The treatment exacerbates the pain. } \\
\hline 9. Concert & Agreement $=$ unison & \\
\hline \multicolumn{3}{|c|}{ e.g. There is no concert between the two families. } \\
\hline 10. Filch & Steal & \\
\hline \multicolumn{3}{|c|}{ e.g. He filched my orange juice. } \\
\hline 11. Watchfulness & Vigil & \\
\hline \multicolumn{3}{|c|}{ e.g. His parents kept vigil beside his bed for weeks before he died. } \\
\hline 12. Fascinate & Captivate & \\
\hline \multicolumn{3}{|c|}{ e.g. Her story fascinates the audience. } \\
\hline 13. Elicit & Extract & \\
\hline \multicolumn{3}{|c|}{ e.g. I can't elicit a noun from this passage. } \\
\hline 14. Discomfit & Embarrass & \\
\hline \multicolumn{3}{|c|}{ e.g. Your remarks discomfited me } \\
\hline 15. Spectacle & Pageant & \\
\hline \multicolumn{3}{|c|}{ e.g. It was a strange spectacle to see the two enemies shaking hands. } \\
\hline 16. Mendacious & Untruthful & \\
\hline \multicolumn{3}{|c|}{ e.g. It was a mendacious statement. } \\
\hline 17. Ponderous & Heavy; Boring & \\
\hline
\end{tabular}


مجلة وادي النيل للاراسات والبحوث الإنسانية و الاجتماعية والتربوية (مجلة علمية محكمة)

(ISSN : 2536 - 9555)

\section{Appendix [A] Sheet 4}

\begin{tabular}{|c|c|c|}
\hline Vocabulary & Synonym & Translation \\
\hline 1. Asymmetric & Different & \\
\hline \multicolumn{3}{|c|}{ e.g. There are asymmetric views concerning this problem. } \\
\hline 2. Frantically & Hurriedly and worriedly & \\
\hline \multicolumn{3}{|c|}{ e.g. I've been working frantically all week to get it finished on time. } \\
\hline 3. Retail & Opposite of wholesale & \\
\hline \multicolumn{3}{|c|}{ e.g. Their products are retailed all over Britain. } \\
\hline 4. Purchase & Buy & \\
\hline \multicolumn{3}{|c|}{ e.g. We purchases a great gift. } \\
\hline 5. Engender & Cause & \\
\hline \multicolumn{3}{|c|}{ e.g. Her latest book has engendered a lot of controversy. } \\
\hline 6. Ambivalent & Conflicted & \\
\hline \multicolumn{3}{|c|}{ e.g. He has ambivalent feelings towards his father. } \\
\hline 7. Relish & Enjoy & \\
\hline \multicolumn{3}{|c|}{ e.g. I relish a challenge. } \\
\hline 8. Bond & Relationships & \\
\hline \multicolumn{3}{|c|}{ e.g. In societies with strong family bonds, people tend to live longer. } \\
\hline 9. Dread & Fear & \\
\hline \multicolumn{3}{|c|}{ e.g. He dreads the exam. } \\
\hline 10. Set out & Start & \\
\hline \multicolumn{3}{|c|}{ e.g. We set out to study hard. } \\
\hline 11. Equate & to consider two things ar & \\
\hline \multicolumn{3}{|c|}{ e.g. Most people equate wealth with success. } \\
\hline 12. Unfounded & Incorrect & \\
\hline \multicolumn{3}{|c|}{ e.g. Your conclusion is unfounded. } \\
\hline 13. Magnitude & Size; Importance & \\
\hline \multicolumn{3}{|c|}{ They don't seem to grasp the magnitude of the problem. } \\
\hline 14. Convey & Communicate & \\
\hline \multicolumn{3}{|c|}{ e.g. Your gift conveys thoughtfulness. } \\
\hline 15. Construe & Explain & \\
\hline \multicolumn{3}{|c|}{ e.g. Any changes to the plan would be construed as indecision. } \\
\hline 16. Ritual & Rites & \\
\hline \multicolumn{3}{|c|}{ e.g. Coffee and the newspaper are part of my morning ritual. } \\
\hline 17. Puzzling & Vague; confusing & \\
\hline
\end{tabular}


Polysemes and Synonym Language Stock:

Linguistic Evidence from English to Arabic Translation

Dr. Mohammad Awad Al-Dawoody Abdulaal

\begin{tabular}{|c|c|c|}
\hline \multicolumn{3}{|c|}{ مجلة وادي النيل للاراسات و البحوث الإنسانية والاجتماعية والتربوية (مجلة علمية محكمة) } \\
\hline & Anpendix [A1 Sheet 5 & \multirow[b]{2}{*}{ Translation } \\
\hline Vocabulary & Synonym & \\
\hline 1. Superficial & Shallow & \\
\hline \multicolumn{3}{|c|}{ e.g. I have only a superficial knowledge of the subject. } \\
\hline 2. Coterie & Clique $=$ group & \\
\hline \multicolumn{3}{|c|}{ e.g. A coterie of writers met the president. } \\
\hline 3. Adversity & Misfortune & \\
\hline \multicolumn{3}{|c|}{ e.g. The road to happiness is paved with adversities. } \\
\hline 4. Foresee & Expect & \\
\hline \multicolumn{3}{|c|}{ e.g. I don't foresee any difficulties so long as we keep within budget. } \\
\hline 5. Nemesis & Enemy; Punishment & \\
\hline \multicolumn{3}{|c|}{$\begin{array}{l}\text { e.g. The tax increases proved to be the president's political nemesis. } \\
\text { e.g. He received the just nemesis. }\end{array}$} \\
\hline 6. Assess & Measure & \\
\hline \multicolumn{3}{|c|}{ e.g. They couldn't agree the best way to assess their students. } \\
\hline 7. Egression & Departure & \\
\hline \multicolumn{3}{|c|}{ e.g. The egression of enemies from Egypt was a historical event. } \\
\hline 8. Amnesty & Pardon & \\
\hline \multicolumn{3}{|c|}{ e.g. The government refused to declare an amnesty for the criminals. } \\
\hline 9. Facet & Aspect & \\
\hline \multicolumn{3}{|c|}{ e.g. He has travelled extensively in China, recording every facet of life. } \\
\hline 10. Annex & Take or add by force & \\
\hline \multicolumn{3}{|c|}{ e.g. The United States annexed parts of Texas. } \\
\hline 11. Pilfer & Steal & \\
\hline \multicolumn{3}{|c|}{ e.g. He was caught pilfering (sweets) from the shop. } \\
\hline 12. Suffice & To be adequate & \\
\hline \multicolumn{3}{|c|}{ e.g. I'm taking $\$ 400$ - I think that should suffice. } \\
\hline 13. Baffle & Frustrate & \\
\hline \multicolumn{3}{|c|}{ e.g. Her answer baffled me. } \\
\hline 14. Gadfly & Annoying person & \\
\hline \multicolumn{3}{|c|}{ e.g. This political party is full of gadflies. } \\
\hline 15. Uniformity & Consistency & \\
\hline \multicolumn{3}{|c|}{ e.g. There seems to be no uniformity among the various systems. } \\
\hline 16. Deify & Worship & \\
\hline \multicolumn{3}{|c|}{ e.g. The Romans used to deify their emperors. } \\
\hline 17. Niggardly & Penurious & \\
\hline
\end{tabular}


مجلة وادي النيل للار اسات و البحوث الإنسانية والاجتماعية والتربوية (مجلة علمية محكمة)

(ISSN : 2536 - 9555)

\section{Appendix [A] Sheet 6}

\begin{tabular}{|l|l|l|}
\hline \multicolumn{1}{|c|}{ Vocabulary } & \multicolumn{1}{|c|}{ Synonym } & Translation \\
\hline 1. Vendetta & Feud & \\
\hline e.g. There is a ten-year-old feud between the two countries \\
\hline 2.Vindictive & Revengeful & \\
\hline e.g. He has vindictive attitudes towards her. \\
\hline 3. Erudite & Having a lot of knowledge \\
\hline e.g. He's the author of an erudite book on Scottish history. \\
\hline 4. Condone & Forgive & \\
\hline e.g. The government should not condone violence. \\
\hline 5. Humdrum & Commonplace & \\
\hline e.g. Most of the work is fairly humdrum. \\
\hline 6. Wise & Judicious \\
\hline e.g. It was a judicious decision. \\
\hline 7. Impeccable & Flawless = perfect & \\
\hline e.g. His English is impeccable. \\
\hline 8. Object & Disapprove \\
\hline e.g. we objected to the new taxes. \\
\hline 9. Delectable & Delightful \\
\hline e.g. Delectable smells rose from the kitchen. \\
\hline 10. Redeem $\mid$ Recover & \\
\hline e.g. He finally redeemed his watch from the pawnbroker. \\
\hline 11. Delegate & Representative & \\
\hline e.g. The delegates walked out of the conference. \\
\hline 12. Abnegation & Self-denial & \\
\hline e.g. It is a heart-warming tale of courage and abnegation. \\
\hline 13. Egregious & Shocking \\
\hline e.g. It was an egregious error. \\
\hline 14. Echelon & Rank \\
\hline e.g. Their clients are from the highest echelons of society. \\
\hline 15. Dilemma & Confusion / problem & \\
\hline e.g. I do not know how to get out of this dilemma \\
\hline 16. Attenuate & Weaken / make thin & \\
\hline e.g. Radiation from the sun is attenuated by the earth's atmosphere. \\
\hline 17. Defer & Postpone \\
\hline e.g. Can we defer making a decision until next week? \\
\hline 18. Miserable & Abject \\
\hline e.g She leads a miserable life. \\
\hline
\end{tabular}


Polysemes and Synonym Language Stock:

Linguistic Evidence from English to Arabic Translation

Dr. Mohammad Awad Al-Dawoody Abdulaal

مجلة وادي النيل للاراسات والبحوث الإنسانية والاجتماعية والتربوية (مجلة علمية محكمة)

\section{Appendix (B)}

\begin{tabular}{|c|c|c|c|}
\hline $\begin{array}{c}\text { Lexical } \\
\text { Items }\end{array}$ & S1 & $\mathbf{S 2}$ & S3 \\
\hline \multicolumn{4}{|l|}{ سهل } \\
\hline \multicolumn{4}{|l|}{ صعب } \\
\hline \multicolumn{4}{|l|}{ غامض } \\
\hline \multicolumn{4}{|l|}{ واضتح } \\
\hline \multicolumn{4}{|l|}{ مجته } \\
\hline \multicolumn{4}{|l|}{ بشع } \\
\hline \multicolumn{4}{|l|}{ كفع } \\
\hline \multicolumn{4}{|l|}{ يفهم } \\
\hline \multicolumn{4}{|l|}{ يسرق } \\
\hline \multicolumn{4}{|l|}{ ياعم } \\
\hline \multicolumn{4}{|l|}{ هام } \\
\hline \multicolumn{4}{|l|}{ صادم } \\
\hline \multicolumn{4}{|l|}{ هام } \\
\hline \multicolumn{4}{|l|}{ اجتماعي } \\
\hline \multicolumn{4}{|l|}{ يسرق } \\
\hline \multicolumn{4}{|l|}{ ضخم } \\
\hline أخرق & & & \\
\hline
\end{tabular}


مجلة وادي النيل للاراسات والبحوث الإنسانية والاجتماعية والتربوية (مجلة علمية محكمة)

(ISSN : 2536 - 9555)

Appendix (C)

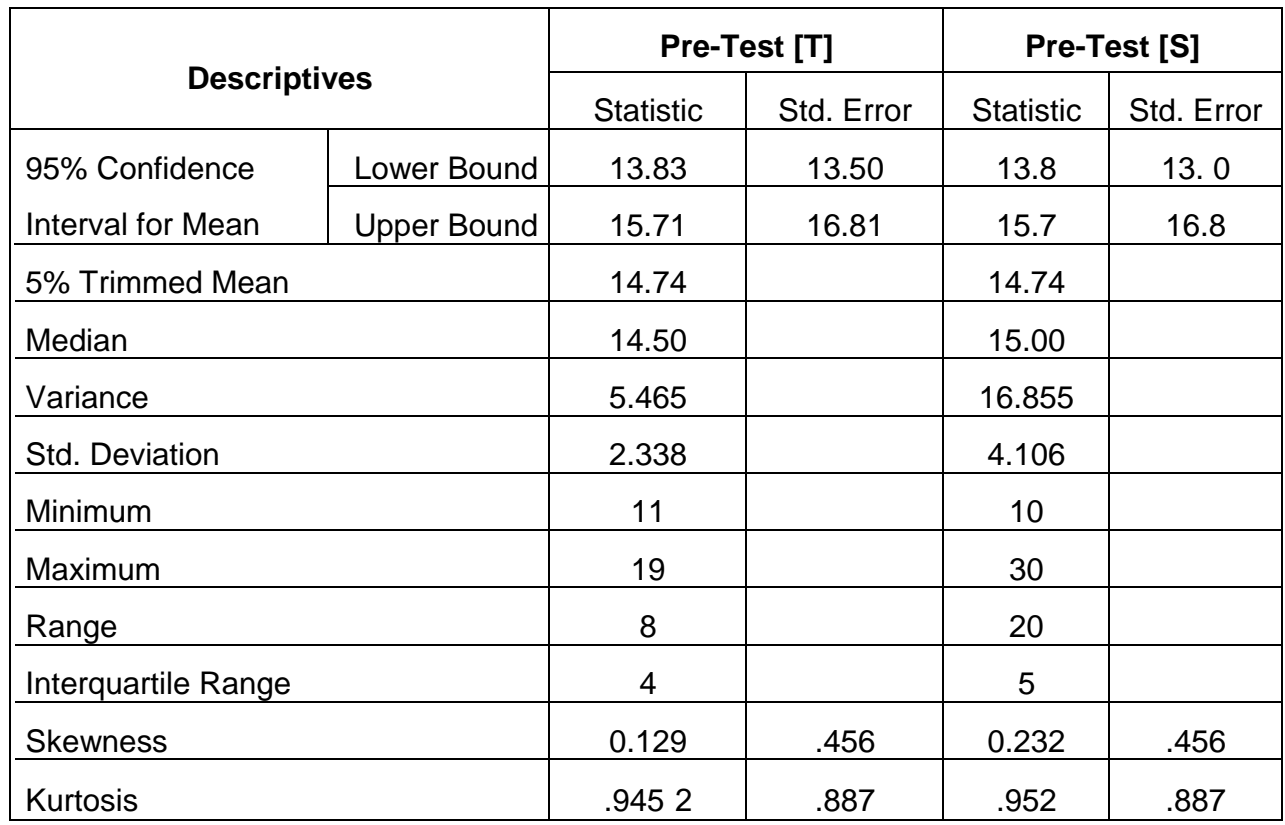

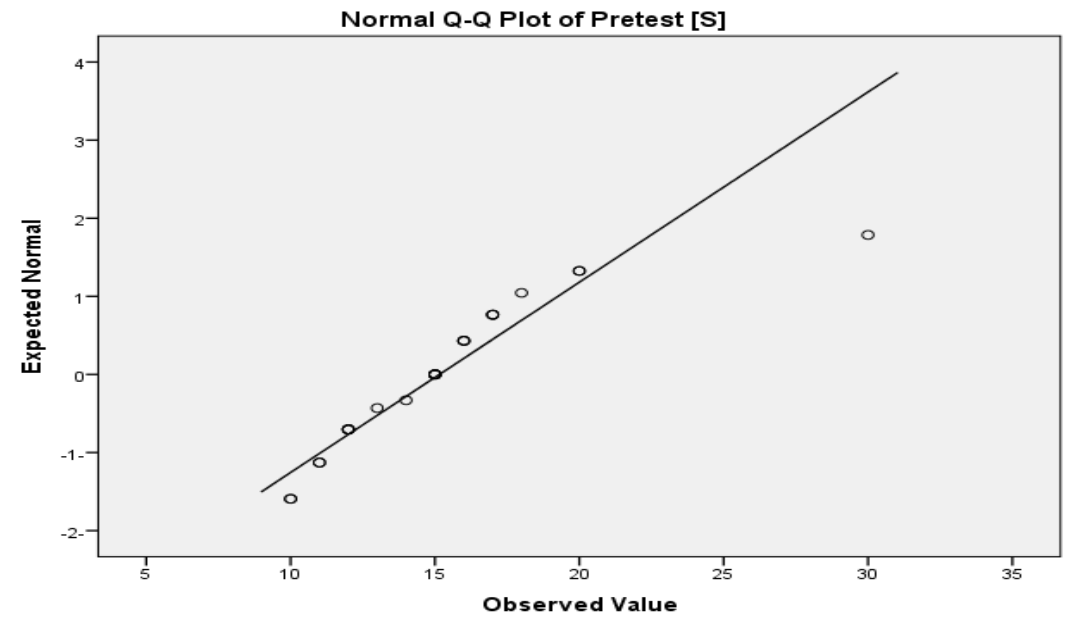


Polysemes and Synonym Language Stock:

Linguistic Evidence from English to Arabic Translation

Dr. Mohammad Awad Al-Dawoody Abdulaal

\section{مجلة وادي النيل للار اسات و البحوث الإنسانية والاجتماعية والتربوية (مجلة علمية محكمة)}
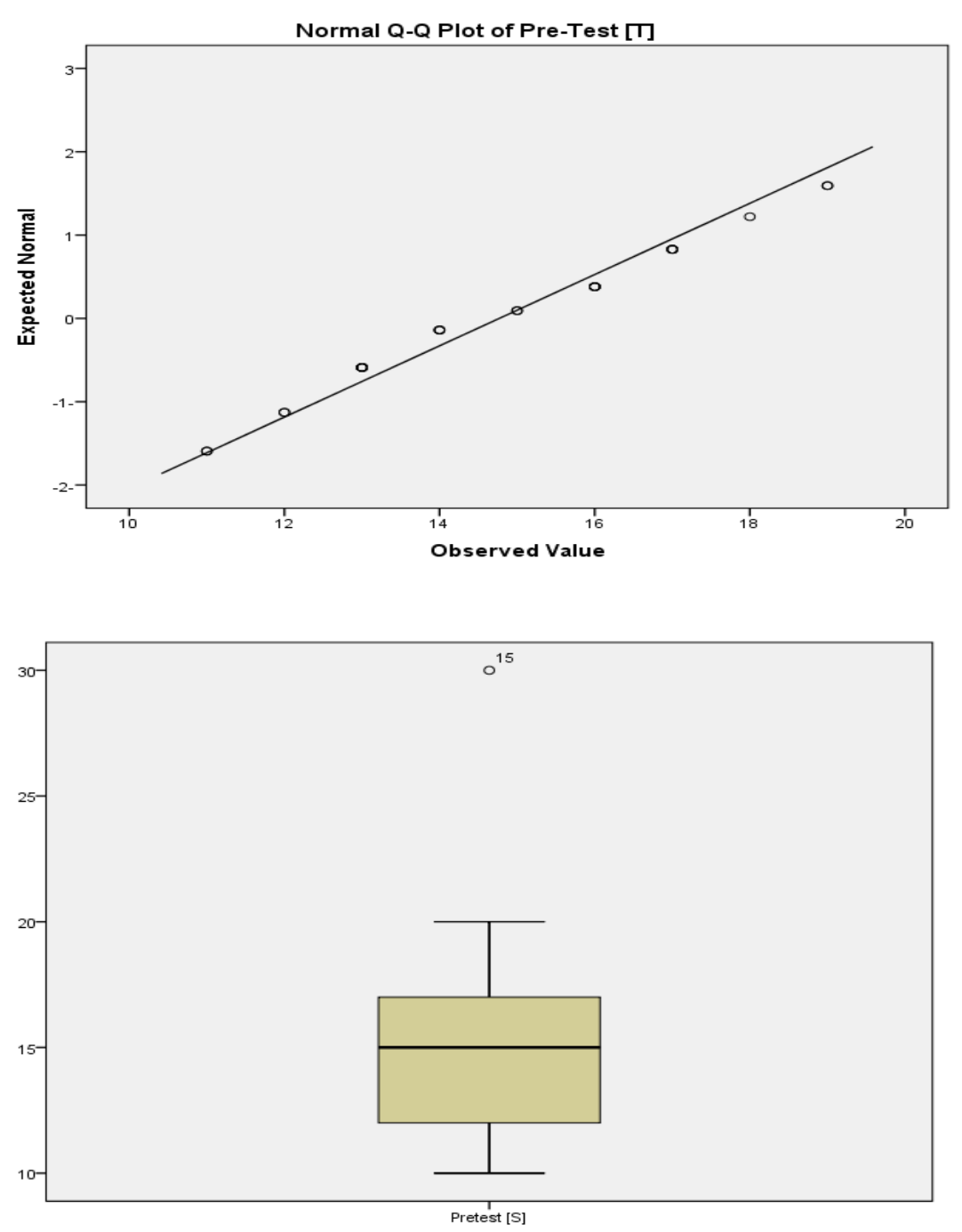
مجلة وادي النيل للار اسات والبحوث الإنسانية والاجتماعية والتربوية (مجلة علمية محكمة)

(ISSN : 2536 - 9555)

\section{Appendix (D)}

\begin{tabular}{|c|c|c|c|c|c|}
\hline \multirow{2}{*}{\multicolumn{2}{|c|}{ Descriptives }} & \multicolumn{2}{|c|}{ Post-Test [T] } & \multicolumn{2}{|c|}{ Post -Test [S] } \\
\hline & & Statistic & Std. Error & Statistic & Std. Error \\
\hline \multirow{2}{*}{$\begin{array}{l}\text { Confidence Interval } \% 95 \\
\text { for Mean }\end{array}$} & Lower Bound & 23.14 & 21.52 & 13.1 & 23. 0 \\
\hline & Upper Bound & 26.24 & 25.41 & 615.5 & 16.8 \\
\hline \multicolumn{2}{|l|}{ 5\% Trimmed Mean } & 25.81 & & 24.86 & \\
\hline \multicolumn{2}{|l|}{ Median } & 26.00 & & 25.00 & \\
\hline \multicolumn{2}{|l|}{ Variance } & 7.892 & & 5.324 & \\
\hline \multicolumn{2}{|l|}{ Std. Deviation } & 2.809 & & 2.307 & \\
\hline \multicolumn{2}{|l|}{ Minimum } & 13 & & 21 & \\
\hline \multicolumn{2}{|l|}{ Maximum } & 30 & & 30 & \\
\hline \multicolumn{2}{|l|}{ Range } & 17 & & 9 & \\
\hline \multicolumn{2}{|l|}{ Interquartile Range } & 4 & & 2 & \\
\hline \multicolumn{2}{|l|}{ Skewness } & 0.2206 & .266 & .014 & .266 \\
\hline \multicolumn{2}{|l|}{ Kurtosis } & .8952 & .526 & .981 & .526 \\
\hline
\end{tabular}

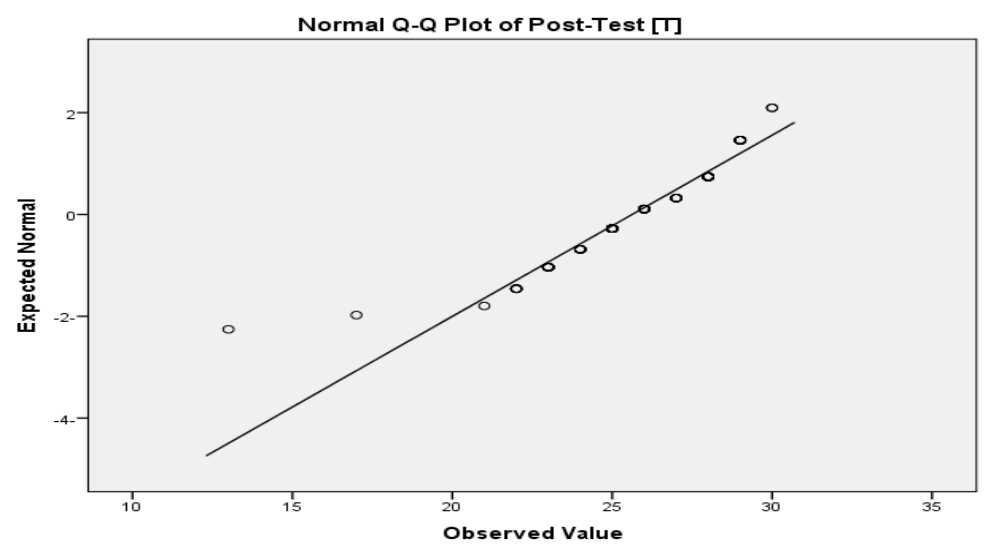


Polysemes and Synonym Language Stock:

Linguistic Evidence from English to Arabic Translation

Dr. Mohammad Awad Al-Dawoody Abdulaal

\section{مجلة وادي النيل للار اسات و البحوث الإنسانية والاجتماعية و التربوية (مجلة علمية محكمة)}
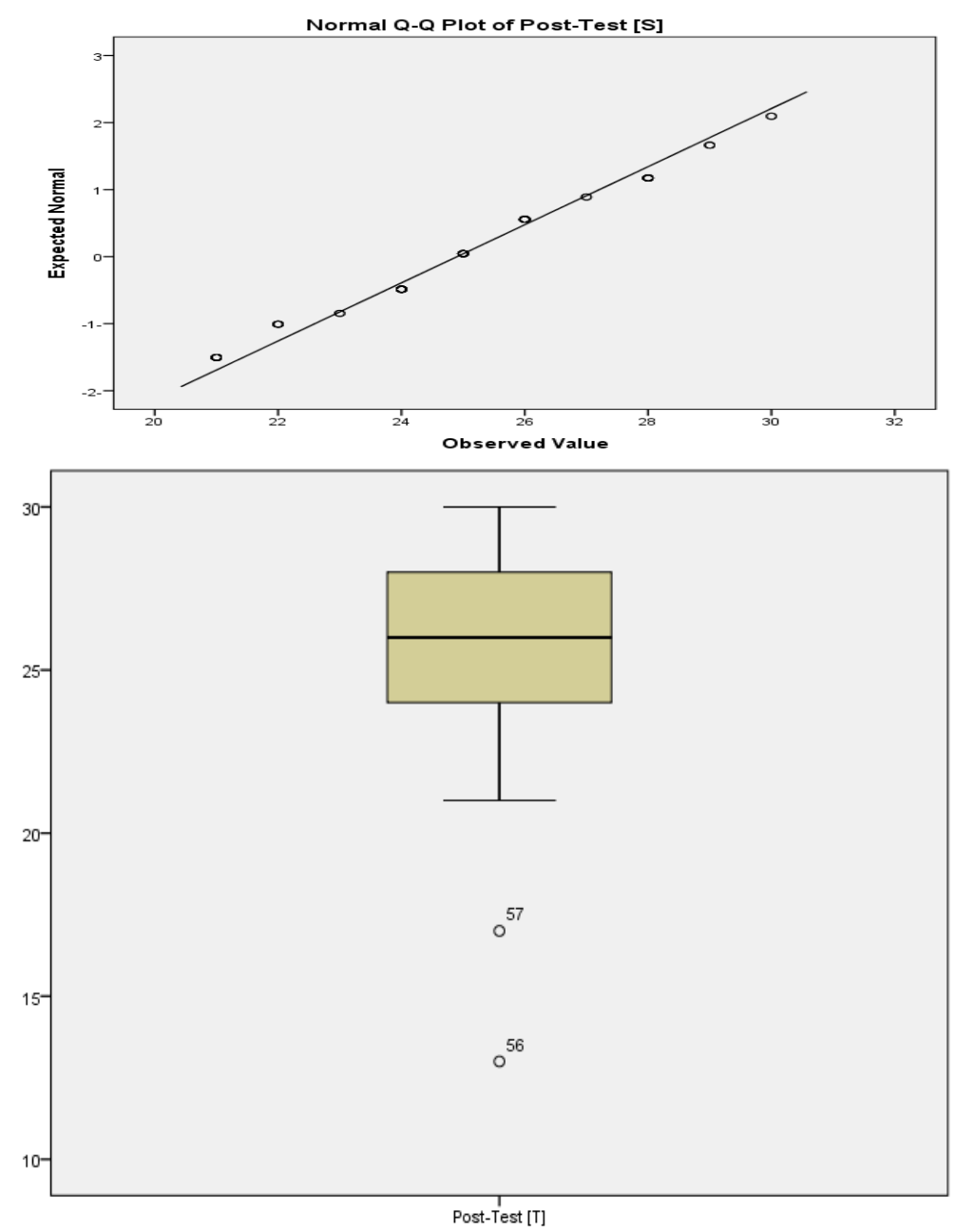
مجلة وادي النيل للار اسات والبحوث الإنسانية والاجتماعية والتربوية (مجلة علمية محكمة)

(ISSN : 2536 - 9555)

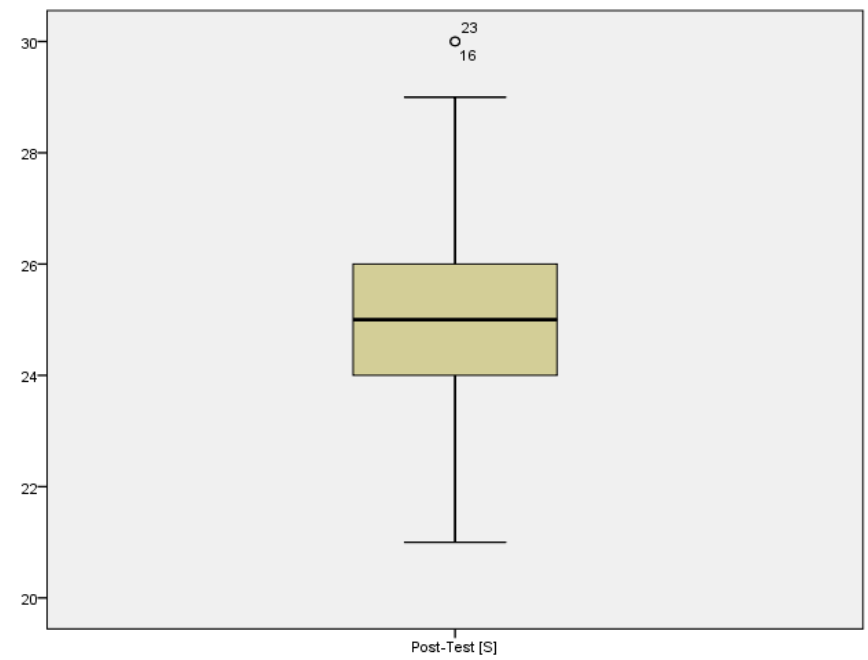

(32) 